\title{
Investigation of $\mathrm{TaC}-\mathrm{TaB}_{2}$ ceramic composites
}

\author{
BEHZAD MEHDIKHANI ${ }^{1, *}$, GHOLAM HOSSEIN BORHANI ${ }^{1}$, SAEED REZA BAKHSHI ${ }^{1}$ \\ and HAMID REZA BAHARVANDI ${ }^{2}$ \\ ${ }^{1}$ Department of Materials Engineering, Malek-e-Ashtar University of Technology, Isfahan, Iran \\ ${ }^{2}$ Department of Materials Engineering, Malek-e-Ashtar University of Technology, Tehran, Iran
}

MS received 28 July 2015; accepted 19 October 2015

\begin{abstract}
The $\mathrm{TaC}-\mathrm{TaB}_{2}$ composition was sintered by spark plasma (SPS) at $1900-2100^{\circ} \mathrm{C}$ and applied pressure of $30 \mathrm{MPa}$. TaC and $2-3 \mathrm{wt} \% \mathrm{~B}_{4} \mathrm{C}$ were used as starting powders. Densification process, phase evolution, microstructure and the mechanical properties of the composites were investigated. The results indicated that the $\mathrm{TaC}_{-}-\mathrm{TaB}_{2}$ composition could be SPS to $97 \%$ of theoretical density in $10 \mathrm{~min}$ at $2100^{\circ} \mathrm{C}$. Addition of $\mathrm{B}_{4} \mathrm{C}$ leads to an increase in the density sample from 76 to $97 \% . \mathrm{B}_{4} \mathrm{C}$ nano-powder resists grain growth even at high temperature $2100^{\circ} \mathrm{C}$. The formation of $\mathrm{TaB}_{2} /$ carbon at $\mathrm{TaC}$ grain boundaries helps in pinning the grain boundary and inhibiting grain growth. The phase formation was associated with carbon and boron diffusion from the starting particles $\mathrm{B}_{4} \mathrm{C}$ to form $\mathrm{TaB}_{2}$ phases. TaC grain sizes decreased with increase in $\mathrm{B}_{4} \mathrm{C}$ concentration. Samples with $2.0 \mathrm{wt} \% \mathrm{~B}_{4} \mathrm{C}$ composition had highest flexure strength up to $520 \mathrm{MPa}$. The effect of $\mathrm{B}_{4} \mathrm{C}$ addition on hardness measured by microhardness has been studied. Hardness of samples containing $3.0 \mathrm{wt} \% \mathrm{~B}_{4} \mathrm{C}$ was $16.99 \mathrm{GPa}$.
\end{abstract}

Keywords. TaC-TaB 2 ; spark plasma sintering; hardness; flexure strength; microstructure.

\section{Introduction}

Tantalum carbide and boride are an important ultra-high temperature ceramic (UHTC) for potential applications at $>2000^{\circ} \mathrm{C}$ [1]. These materials have attracted interest in recent years due to the increased demand for higher performance materials for applications in extremely harsh environments, such as propulsion systems for future hypersonic vehicles [2-5]. Tantalum carbide ceramics are difficult to densify because of the rapid grain growth of $\mathrm{TaC}_{\mathrm{y}}$ [6-8], which leads to entrapped porosity. One of the methods to inhibit grain growth is by reductive agents such as $\mathrm{C}$ and $\mathrm{B}_{4} \mathrm{C}$ to eliminate the oxides impurities [8]. These impurities $[7,8]$ resulted in enhanced $\mathrm{TaC}$ grain growth during densification, which could be due to liquid phase formation, evaporation condensation or other mechanisms. Other beneficial approaches included using extremely fine starting powders $[9,10]$ or adding a UHTC diboride to physically pin grain growth [7]. Another method for increasing the final density is reducing the particle size of the powders. Research shows that finer powder produces a higher final density than coarser powder, particularly when decreasing from the micrometre to the nanometre scale [11]. This indicates that starting with nanoscale powders would be beneficial in sintering $\mathrm{TaC}$, which is normally difficult to densify. However, research by Sommer et al [12] shows that rapid grain growth can occur (from 100 to $500 \mathrm{~nm}$ ) during conventional sintering, particularly in carbide ceramics. Kim et al [13] have shown that

\footnotetext{
*Author for correspondence (Beh_mehdikhani@yahoo.com)
}

initial particle size is essential to the final density of TaC during high heating rate experiments, with larger particle size indicating a lower final density. Another method for increasing the final density is by spark plasma sintering (SPS). Spark plasma sintering is a relatively novel consolidation method that has the advantage of short sintering duration and has shown better densification and properties than hot pressing. SPS has been extensively used for synthesis of UHTCs and their composites [2]. Optimization of sintering conditions and microstructural parameters led to the following mechanical property: flexural strength ranging from 670 to $900 \mathrm{MPa}$ for $\mathrm{TaC}$-based ceramics [14]. In this work, the densification, microstructure, mechanical properties of $\mathrm{TaC}-\mathrm{TaB}_{2}$ composites were investigated. In this study, $2-3 \mathrm{wt} \% \mathrm{~B}_{4} \mathrm{C}$ was added to reaction (1) and modified it by:

$$
2 \mathrm{TaC}+\mathrm{B}_{4} \mathrm{C} \rightarrow 2 \mathrm{TaB}_{2}+3 \mathrm{C} .
$$

The main novelty of this work is the use of synthesized nanometric powders and discussion about $\mathrm{TaC}-\mathrm{TaB}_{2}$ composites.

\section{Experimental}

\subsection{Raw material}

The raw material characteristics are listed in table 1. Purity of $\mathrm{TaC}$ powder was higher than $99 \%$. The main impurities were $0.3 \mathrm{wt} \% \mathrm{Nb}, 0.1 \mathrm{wt} \% \mathrm{Fe}, 0.20 \mathrm{wt} \% \mathrm{O}, 0.15 \mathrm{wt} \%$ free carbon, $0.05 \mathrm{wt} \% \mathrm{~N}$, and $\mathrm{Al}, \mathrm{Ca}, \mathrm{K}, \mathrm{Na}$, Ti with a total amount $<0.05 \mathrm{wt} \%$. $\mathrm{B}_{4} \mathrm{C}$ was $>95 \mathrm{wt} \%$ pure with major impurities of 
free carbon. Preparation and properties of the powders were the same as detailed in previous paper [15].

\subsection{Spark plasma sintering}

Spark plasma sintering (SPS) was utilized to consolidate $\mathrm{TaC}-\mathrm{B}_{4} \mathrm{C}$ and $\mathrm{TaC}-\mathrm{TaB}_{2}$ powders. SPS was carried out in Argon atmosphere at 1900 to $2100^{\circ} \mathrm{C}$. The heating rate of $100^{\circ} \mathrm{C} \mathrm{m^{-1 }}$ was adopted to reach the maximum temperature with a hold time of $10 \mathrm{~min}$. SPS was carried out at $30 \mathrm{MPa}$ pressure. The powders were pressed in graphite dies and punches with approximately 4-5 mm thick and $15 \mathrm{~mm}$ in diameter. In this work, to prevent the sticking of powder to dies, graphite foil was used around the powders. Theoretical density for the sintered composites was determined by the law of mixtures. Bulk densities were measured by the Archimedes method. Relative density and open porosity were calculated. Phase compositions were analysed by $\mathrm{X}$-ray diffraction (XRD). The lattice parameter $(a)$ for the cubic $\mathrm{TaC}_{\mathrm{y}}$ was calculated by refining the XRD. The $\mathrm{C} / \mathrm{Ta}$ ratio in the $\mathrm{TaC}_{\mathrm{y}}$ was determined according to equation (2) given by Storms [8].

$$
\mathrm{C} / \mathrm{Ta}=-25.641+5.9757 a_{0}
$$

Microhardness was measured using Vickers' indentation (Model 3202, zwick) by applying a load of $2.0 \mathrm{~kg}(19.6 \mathrm{~N})$. To measure three-point flexural strength, the specimens were cut in dimensions $1 \times 0.5 \mathrm{~cm}$ and their edges were polish for elimination of micro-cracks. Three-point bending strength was measured in a mechanical load frame (SANAF1 TON). This machine has delicate jaw for small samples. Microstructure was observed by field-emission scanning electron microscopy (FE-SEM). The samples were sectioned, ground and were polished to $1 \mu \mathrm{m}$ diamond finish.

\section{Result and discussion}

XRD spectra, phase assembles, relative density (\%), lattice parameter $(\AA)$ and the calculated $\mathrm{C} / \mathrm{Ta}$ ratios for cubic $\mathrm{TaC}_{\mathrm{y}}$

Table 1. Raw material characteristics.

\begin{tabular}{lccc}
\hline Material & Purity & Particle size & Supplier \\
\hline $\mathrm{TaC}$ & $99 \%$ & $1.25 \mu \mathrm{m}$ & $\begin{array}{c}\text { Ningxia Orient } \\
\text { Jingangzuan }\end{array}$ \\
$\mathrm{B}_{4} \mathrm{C}$ & $>95 \mathrm{wt} \%$ & $300 \mathrm{~nm}$ & . \\
\hline
\end{tabular}

in the $\mathrm{TaC} / \mathrm{TaB}_{2}$ composites SPS for $10 \mathrm{~min}$ at different temperatures are shown in table 2.

\subsection{XRD and thermodynamic calculation}

Figure 1 exhibits predominant cubic $\mathrm{TaC}_{\mathrm{y}}$, hexagonal $\mathrm{TaB}_{2}$ and carbon. No other crystalline phases (if present) were revealed in the XRD spectra to the detecting limit of XRD. This meant the $\mathrm{B}_{4} \mathrm{C}$ particle had completely decomposed, and $\mathrm{B}$ and $\mathrm{C}$ were incorporated into the $\mathrm{TaC}$ lattice to form $\mathrm{TaC}_{\mathrm{y}}$ and $\mathrm{TaB}_{2}$, despite of some $\mathrm{B}$ and $\mathrm{C}$ loss by reducing oxide impurities $[8,16]$. TaC in the starting powder had regulated its stoichiometry and contributed part of the $\mathrm{TaC}_{\mathrm{y}}$ contents. A commercial software program (HSC Chemistry, Fairfield, CA, USA) was used to identify the probable reaction using thermodynamic data. The change in standard Gibbs free energy $\left(\Delta G^{\circ}\right)$ indicated that reaction (1) was favourable across the range of processing temperatures, which suggested that $\mathrm{B}_{4} \mathrm{C}$ reacted with $\mathrm{TaC}$ to form $\mathrm{TaB}_{2}$ and $\mathrm{C}$ :

$\Delta G^{\circ}=-66.4+0.0103 \mathrm{~T}(\mathrm{~kJ})$ favourable across the processing temperature range. $\mathrm{TaC}$ is not chemically compatible with $\mathrm{B}_{4} \mathrm{C}$. For the overall composition produced by adding relatively small amounts of $\mathrm{B}_{4} \mathrm{C}$ to $\mathrm{TaC}$, the phase diagram indicated that $\mathrm{TaB}_{2}$ and $\mathrm{C}$ were stable with $\mathrm{TaC}$ [15]. Analysis of the XRD patterns (figure 1) showed a progressive increase in the amount of the $\mathrm{TaB}_{2}$ phase formed during SPS when the $\mathrm{B}_{4} \mathrm{C}$ addition was increased from 2.0 to $3.0 \mathrm{wt} \%$. The amounts of $\mathrm{TaB}_{2}$ formed could be as high as $14.0 \mathrm{wt} \%$ for a $\mathrm{B}_{4} \mathrm{C}$ addition of 2.0 and $22.0 \mathrm{wt} \%$ for $\mathrm{a} \mathrm{B}_{4} \mathrm{C}$ addition of $3.0 \mathrm{wt} \%$, if all of the $\mathrm{B}_{4} \mathrm{C}$ were consumed by reaction (1). Rietveld refinement of XRD patterns shows that when $2.0 \mathrm{wt} \% \mathrm{~B}_{4} \mathrm{C}$ was added, spark plasma sintered ceramic contained $89 \mathrm{wt} \% \mathrm{TaC}$ and $11 \mathrm{wt} \% \mathrm{TaB}_{2}$. When $3.0 \mathrm{wt} \%$ $\mathrm{B}_{4} \mathrm{C}$ was added, the spark plasma sintered ceramic contained $82.0 \mathrm{wt} \% \mathrm{TaC}$ and $18.0 \mathrm{wt} \% \mathrm{TaB}_{2}$. The amounts of $\mathrm{TaB}_{2}$ detected by XRD were less than the stoichiometric amounts predicted using reaction (1), indicating that some of the $\mathrm{B}_{4} \mathrm{C}$ had reacted with surface oxides (e.g., $\mathrm{Ta}_{2} \mathrm{O}_{5}$ ) instead of $\mathrm{TaC}$. The relative densities of the materials were significantly improved by increasing the SPS temperature from 1900 to $2100^{\circ} \mathrm{C}$ (table 2 ).

$\mathrm{TaC}$ without additive and $\mathrm{TaC}-2.0 \mathrm{wt} \% \mathrm{~B}_{4} \mathrm{C}$ after sintering at $1900^{\circ} \mathrm{C}$ had relative density of 66 and $\sim 76 \%$. $\mathrm{B}_{4} \mathrm{C}$ in these samples cause density increase at same temperature. When the SPS was increased to $1900^{\circ} \mathrm{C}$ or above, the open

Table 2. Relative density, phase assemble and lattice parameter of the $\mathrm{TaC}-\mathrm{B}_{4} \mathrm{C}$ composites.

\begin{tabular}{lccccc}
\hline Samples & $\begin{array}{c}\text { Sintering temperature } \\
\left({ }^{\circ} \mathrm{C}\right)\end{array}$ & $\begin{array}{c}\text { Theoretical density } \\
\left(\mathrm{g} \mathrm{cm}^{-3}\right)\end{array}$ & $\begin{array}{c}\text { Relative density } \\
(\%)\end{array}$ & $\begin{array}{c}\text { Lattice parameter } \\
(\AA)\end{array}$ & $\mathrm{TaC}_{\mathrm{y}} \mathrm{C} / \mathrm{Ta}$ \\
\hline $\mathrm{TaC}$ & 1900 & 14.3 & 66 & 4.448 & 0.9389 \\
$\mathrm{TaC}-2 \mathrm{wt} \% \mathrm{~B}_{4} \mathrm{C}$ & 1900 & 13.241 & 76.07 & 4.4588 & 1.003 \\
$\mathrm{TaC}-2 \mathrm{wt} \% \mathrm{~B}_{4} \mathrm{C}$ & 2000 & 13.241 & 92.3 & 4.4585 & 1.001 \\
$\mathrm{TaC}-2 \mathrm{wt} \% \mathrm{~B}_{4} \mathrm{C}$ & 2100 & 13.241 & 94.81 & 4.4584 & 1.001 \\
$\mathrm{TaC}-3 \mathrm{wt} \% \mathrm{~B}_{4} \mathrm{C}$ & 2100 & 12.68 & 97.3 & 4.4590 & 1.004 \\
\hline
\end{tabular}




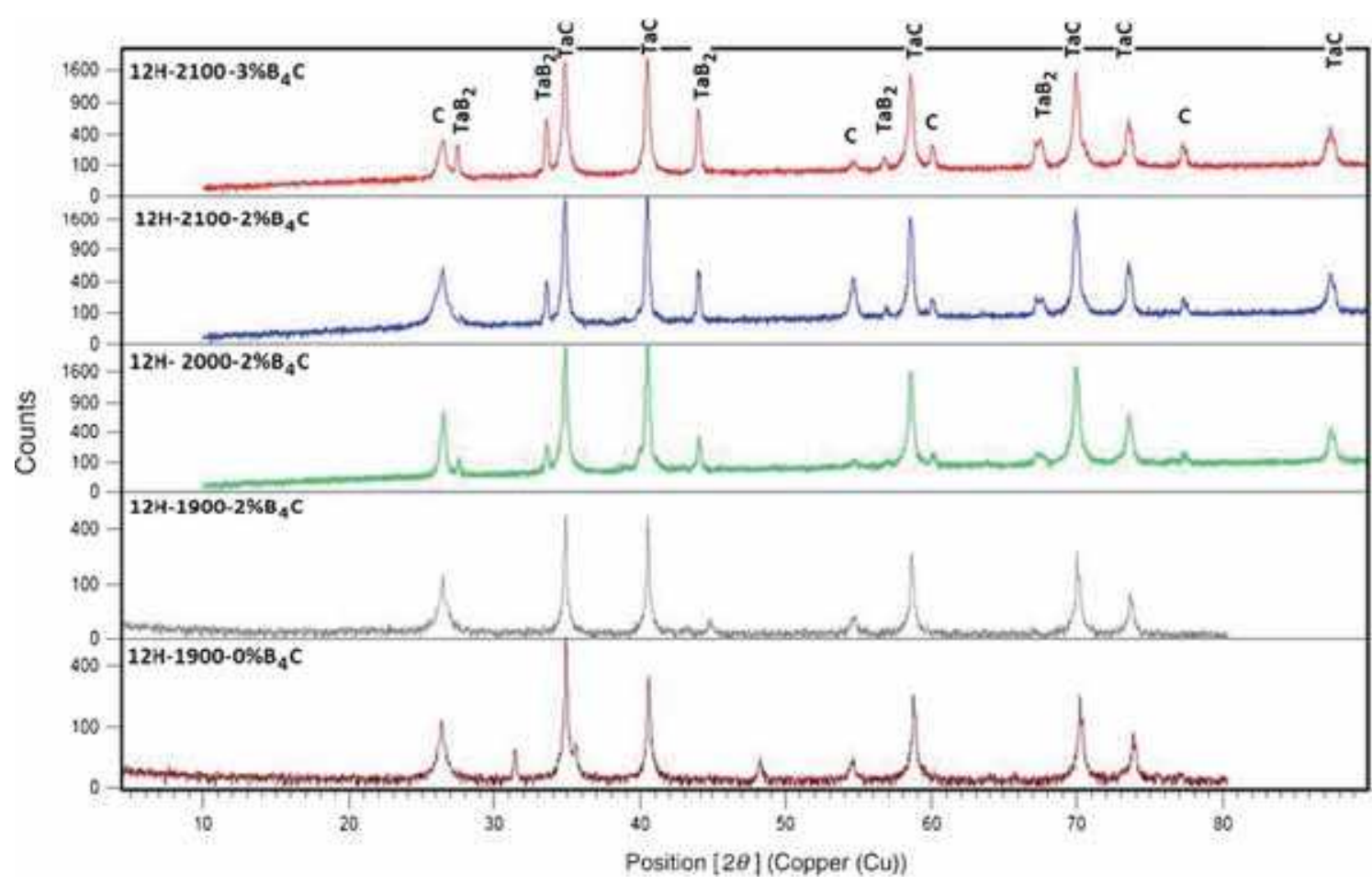

Figure 1. X-ray diffraction patterns of the $\mathrm{TaC}^{\mathrm{T}} \mathrm{TaB}_{2}$ composites spark plasma sintered at $1900-2100^{\circ} \mathrm{C}$.

Table 3. Mechanical properties of $\mathrm{TaC}-\mathrm{B}_{4} \mathrm{C}$ composites.

\begin{tabular}{lcccc}
\hline Samples & $\begin{array}{c}\text { Sintering temperature } \\
\left({ }^{\circ} \mathrm{C}\right)\end{array}$ & $\begin{array}{c}\text { Vickers' hardness } \\
(\mathrm{GPa})\end{array}$ & $\begin{array}{c}\text { Thickness of the samples } \\
(\mathrm{mm})\end{array}$ & $\begin{array}{c}\text { Flexure strength } \\
(\mathrm{MPa})\end{array}$ \\
\hline $\mathrm{TaC}$ & 1900 & 14.98 & 1.2 & 380 \\
$\mathrm{TaC}-2 \mathrm{wt} \% \mathrm{~B}_{4} \mathrm{C}$ & 1900 & 15.14 & 1.1 & 361 \\
$\mathrm{TaC}-2 \mathrm{wt} \% \mathrm{~B}_{4} \mathrm{C}$ & 2000 & 15.44 & 1.0 & 450 \\
$\mathrm{TaC}-2 \mathrm{wt} \% \mathrm{~B}_{4} \mathrm{C}$ & 2100 & 16.93 & 1.2 & 520 \\
TaC-3 wt\% B $4 \mathrm{C}$ & 2100 & 16.99 & 1.4 & 469 \\
\hline
\end{tabular}

pores were completely closed. Relative density reached 94.8 and $97.3 \%$ for 2.0 and $3.0 \mathrm{wt} \% \mathrm{~B}_{4} \mathrm{C}$, respectively, in $2100^{\circ} \mathrm{C}$ sintering temperature. $\mathrm{B}_{4} \mathrm{C}$ in base materials of these samples formed $\mathrm{TaB}_{2}$ phase inside TaC grains. Table 2 shows $\mathrm{C} / \mathrm{Ta}$ ratios for the cubic $\mathrm{TaC}_{\mathrm{y}}$ in different materials. The $\mathrm{C} / \mathrm{Ta}$ values increased with SPS temperature from 1900 to $2000^{\circ} \mathrm{C}$. Carbon further dissolving into the $\mathrm{TaC}_{\mathrm{y}}$ lattice at higher temperatures was accounted for the $\mathrm{C} / \mathrm{Ta}$ ratio increase. In addition, elemental impurities such as $\mathrm{Ti}, \mathrm{Cr}, \mathrm{Fe}$ incorporation into $\mathrm{TaC}_{\mathrm{y}}$ lattice may also extend the $\mathrm{TaC}_{\mathrm{y}}$ lattice, resulting in an over estimation of the $\mathrm{C} / \mathrm{Ta}$ ratio. However, the largest ratio $(\mathrm{C} / \mathrm{Ta}=0.9389)$ calculated for $\mathrm{TaC}$ at $1900^{\circ} \mathrm{C}$ material was still lower than the $(\mathrm{C} / \mathrm{Ta}=1)$ predication by reaction (2). This was due to loss of some $\mathrm{C}$ by forming $\mathrm{CO}[8,16]$. Samples containing $\mathrm{B}_{4} \mathrm{C}$ had $\mathrm{C} / \mathrm{Ta}$ ratio more than $\mathrm{TaC}$ sample. Carbon in $\mathrm{B}_{4} \mathrm{C}$ increase $\mathrm{C} / \mathrm{Ta}$ ratio by dissolving more carbon in $\mathrm{TaC}$ lattice. The hexagonal tantalum diboride may also form a substoichiometric $\mathrm{TaB}_{2-x}$ instead of stoichiometric $\mathrm{TaB}_{2}$. In this study, however, the stoichiometry of this hexagonal tantalum diboride phase was not determined due to lack of necessary references [7].

\subsection{Mechanical properties}

The mechanical properties (hardness, flexure strength) of samples are included in table 3 . Increase in sintering temperature from 1900 to $2100^{\circ} \mathrm{C}$ increase hardness of samples. It may be due to increase in density at higher temperature. Increase of $\mathrm{B}_{4} \mathrm{C}$ leads to the formation of more $\mathrm{TaB}_{2}$ phase. Vickers' hardness increased from 14.1 GPa for monolithic $\mathrm{TaC}$ to $16.99 \mathrm{GPa}$ for TaC-10 wt\% (11 vol\%) $\mathrm{TaB}_{2}$, which was attributed to the higher density achieved for the composite and the higher hardness of the dispersed $\mathrm{TaB}_{2}$ phase (24.5 GPa) compared with monolithic TaC [8].

The flexure strength of the samples increased with increase in sintering temperature. This factor plays an important role in increasing the density of the samples. The flexure strength of the samples increased with increase in $\mathrm{B}_{4} \mathrm{C}$ up to $2.0 \mathrm{wt} \%$, 

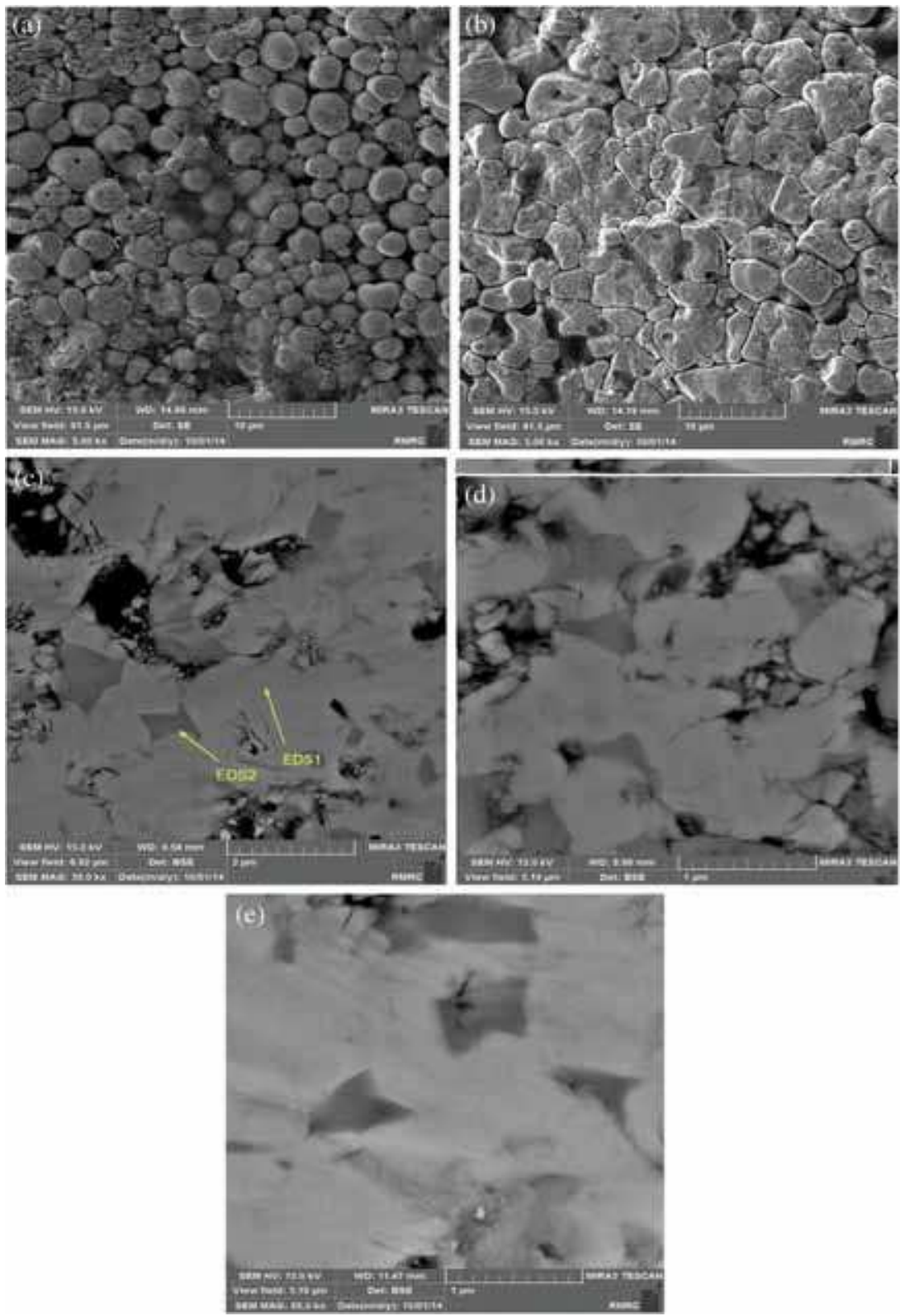

Figure 2. FE-SEM image of sintered samples. (a) $\mathrm{TaC}-0 \% \quad \mathrm{~B}_{4} \mathrm{C}, \quad 1900^{\circ} \mathrm{C}$; (b) $\mathrm{TaC}-2 \% \mathrm{~B}_{4} \mathrm{C}, 1900^{\circ} \mathrm{C}$; (c) $\mathrm{TaC}-2 \% \mathrm{~B}_{4} \mathrm{C}, 2000^{\circ} \mathrm{C}$; (d) $\mathrm{TaC}-2 \% \mathrm{~B}_{4} \mathrm{C}, 2100^{\circ} \mathrm{C}$ and (e) $\mathrm{TaC}-3 \% \mathrm{~B}_{4} \mathrm{C}, 2100^{\circ} \mathrm{C}$.

but further increases of $\mathrm{B}_{4} \mathrm{C}$ reduced the flexural strength composite. Flexure strength of $\mathrm{TaB}_{2}$ was $600 \mathrm{MPa}$, with a maximum of $765 \mathrm{MPa}$ and a minimum of $467 \mathrm{MPa}$. The strength values are comparable to the strength of the monolithic TaC (686 MPa on average). So increase of phase $\mathrm{TaB}_{2}$ causes reduction in the overall flexure strength of the sample containing $3.0 \mathrm{wt} \% \mathrm{~B}_{4} \mathrm{C}$.

\subsection{Microstructure development}

FE-SEM analysis of the microstructure of $\mathrm{TaC}$ with and without $\mathrm{B}_{4} \mathrm{C}$ additions and SPS at various temperatures (figure 2) is included for comparison.
The $\mathrm{TaC}-\mathrm{TaB}_{2}$ composition reached $\sim 76 \%$ of the theoretical density after SPS at $1900 \mathrm{C}$ or above as shown in table 2 . In figure $2 \mathrm{c}-\mathrm{e}$, the dark and grey contrasts are attributed to the $\mathrm{TaC}$ and the $\mathrm{TaB}_{2}$ phase, respectively. The bulk densities of TaC-2.0 wt \% $\mathrm{B}_{4} \mathrm{C}$ sintered by SPS at 1900, 2000 and $2100^{\circ} \mathrm{C}$ were about 76,92 and $94 \%$, respectively. The true density was calculated to be $13241 \mathrm{~g} \mathrm{~cm}^{-3}$ using volumetric rule of mixtures and measured composition. For comparison, Zhang et al [8] found that the relative densities of the $\mathrm{TaC}-10 \mathrm{wt} \%$ (11 vol\%) $\mathrm{TaB}_{2}$ powder hot pressed at 2100 and $2200^{\circ} \mathrm{C}$ were 85 and $89 \%$ after hot pressing at 2100 and $2200^{\circ} \mathrm{C}$, respectively. Enhanced densification of $\mathrm{TaC}$ with the $\mathrm{TaB}_{2}$ addition is likely due to physical pinning 


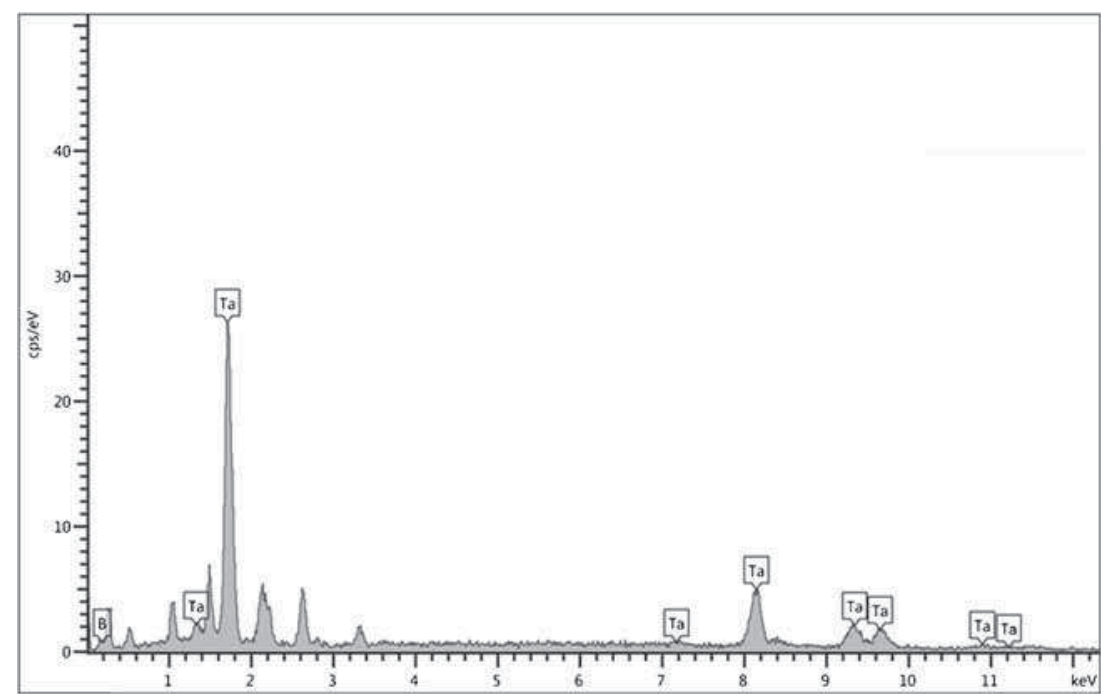

Figure 3. EDS analysis of sample $\mathrm{TaC}-2 \% \mathrm{~B}_{4} \mathrm{C}$ at $2000^{\circ} \mathrm{C}$.
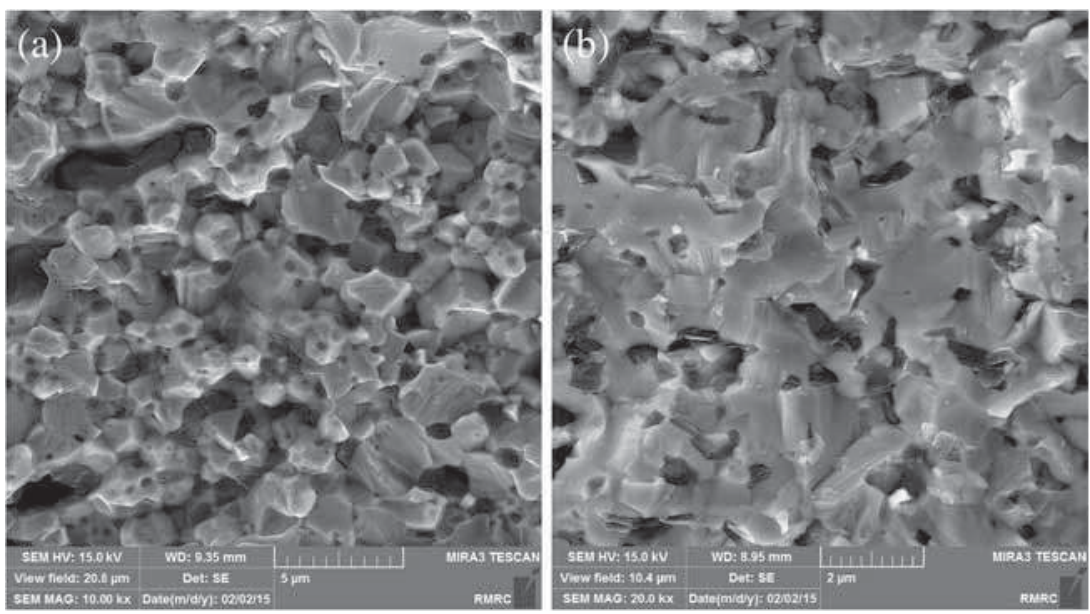

Figure 4. Cross-section of samples (a) $\mathrm{TaC}-0 \% \mathrm{~B}_{4} \mathrm{C}$ at $1900^{\circ} \mathrm{C}$ and (b) $\mathrm{TaC}-3 \% \mathrm{~B}_{4} \mathrm{C}$ at $2100^{\circ} \mathrm{C}$.

of grain growth by the second phase. In addition to grain pinning, the presence of $\mathrm{B}_{2} \mathrm{O}_{3}$ on the $\mathrm{TaB}_{2}$ particles' surface may facilitate grain rearrangement due to the formation of a liquid phase, which would enhance densification. A similar grain growth-pinning effect has been observed in the $\mathrm{ZrB}_{2}-\mathrm{SiC}$ and $\mathrm{HfB}_{2}-\mathrm{SiC}$ systems. In these systems, dispersed $\mathrm{SiC}$ particles have been shown to inhibit the grain growth and enhance densification of the matrix phase [8]. With increase in temperature and $\mathrm{B}_{4} \mathrm{C}$ up to $3 \mathrm{wt} \%$, the density increased. $\mathrm{TaB}_{2}$ is also seen in more in $\mathrm{TaC}$ phase. The size of the $\mathrm{TaC}$ grains could not be determined (in figure $2 \mathrm{c}-\mathrm{e}$ ) because the grain boundaries of $\mathrm{TaC}$ could not be distinguished in the polished crosssections. Repeated attempts at thermal etching to reveal the grain boundaries were not successful. Figure $2 \mathrm{c}-\mathrm{e}$ shows that grain size of newly formed $\mathrm{TaB}_{2}$ increased by sintering temperature from 400 to $700 \mathrm{~nm}$. EDS analysis of sample $\mathrm{TaC}-2 \% \mathrm{~B}_{4} \mathrm{C}$ at $2000^{\circ} \mathrm{C}$ is shown in figure 3 .
Cross-section of samples (a) $\mathrm{TaC}-0 \% \mathrm{~B}_{4} \mathrm{C}$ at $1900^{\circ} \mathrm{C}$ and (b) $\mathrm{TaC}-3 \% \mathrm{~B}_{4} \mathrm{C}$ at $2100^{\circ} \mathrm{C}$ is shown in figure 4 . The size of the $\mathrm{TaC}$ grains in sample $\mathrm{TaC}-0 \% \mathrm{~B}_{4} \mathrm{C}$ at $1900^{\circ} \mathrm{C}$ is $2-3$ micron and size of the $\mathrm{TaC}$ grains in sample $\mathrm{TaC}-3 \% \mathrm{~B}_{4} \mathrm{C}$ at $2100^{\circ} \mathrm{C}$ is 300 to $500 \mathrm{~nm}$.

\section{Conclusion}

TaC- $\mathrm{B}_{4} \mathrm{C}$ powder was sintered by spark plasma sintering at temperatures ranging from 1900 to $2100^{\circ} \mathrm{C}$, achieving a relative density of $66.0 \%$ at $1900^{\circ} \mathrm{C}$ and a $30 \mathrm{MPa}$ applied pressure without the use of sintering additives. $\mathrm{B}_{4} \mathrm{C}$ additive was subsequently used to react with $\mathrm{TaC}$ powder. The onset temperature for densification of $\mathrm{TaC}$ was lowered through the use of $\mathrm{B}_{4} \mathrm{C}$ additive. $\mathrm{TaC}$ with $2.0 \mathrm{wt} \% \mathrm{~B}_{4} \mathrm{C}$ additions could be sintered to $94.8 \%$ density at $2100^{\circ} \mathrm{C}$ with minimal grain growth and mostly intergranular porosity. Increase in $\mathrm{B}_{4} \mathrm{C}$ up to $3.0 \mathrm{wt} \%$ increases the relative 
densification up to $97.3 \%$ and the hardness of samples to $16.99 \mathrm{GPa}$. Flexure strength of the sample containing $2.0 \mathrm{wt} \% \mathrm{~B}_{4} \mathrm{C}$ increased up to $520 \mathrm{MPa}$ and in future increasing $\mathrm{B}_{4} \mathrm{C}$ up to $3.0 \mathrm{wt} \%$, flexure strength of the sample reduced because flexure strength of $\mathrm{TaB}_{2}$ balk is lower than $\mathrm{TaC}$.

\section{Acknowledgements}

We are indebted to material department in Malek-e-Ashtar University of Technology, which supplied the raw materials for the development of this research and to building and construction department of Standard Research Institute for its equipment support.

\section{References}

[1] Liu L, Yea F, Hea X and Zhoua Y 2011 Mater. Chem. Phys. 126459

[2] Mehdikhani B and Bakhshi S R 2014 J. Optoelectronic Adv. Mater. 161311

[3] Wuchina E, Opila E, Opeka M, Fahrenholtz W and Talmy I 2007 Electrochemical Society Interface 1630
[4] Johnson M, Gasch M and Lawson J W 2008 Am. Inst. Aeronautics Astronautics

[5] Justin J F and Jankowiak A 2011 Onera J. Aerospace Lab 3 1-11

[6] Samonov G V and Petrikina R Y 1970 Phys. Sinter. 21

[7] Zhang X, Hilmas G E and Fahrenholtz W G 2008 J. Am. Ceram. Soc. 914129

[8] Zhang X, Hilmas G E and Fahrenholtz W G 2007 J. Am. Ceram. Soc. 90393

[9] Liu J X, Kan Y M and Zhang G J 2010 J. Am. Ceram. Soc. 93 370

[10] Kim B, Woo K, Doh J, Yoon J and Shon I 2009 Ceram. Int. 353395

[11] Shen Z, Johnsson M, Zhao Z and Nygren M $2002 \mathrm{~J}$. Am. Ceram. Soc. $\mathbf{8 5} 1921$

[12] Sommer M, Schubert W D, Zobetz E and Warbichler P 2002 Int. J. Refract. Metal Hard Mater. 2041

[13] Khaleghi E, Lin Y S, Meyers M A and Olevsky E A 2010 Scripta Materialia 63577

[14] Silvestroni L, Bellosi A, Melandri C, Sciti D, Liu J and Zhang G 2011 J. Eur. Ceram. Soc. 31619

[15] Mehdikhani B and Borhani G H 2014 J. Optoelectronic Adv. Mater. 16524

[16] Talmy I G, Zaykoski J A and Opeka M M 2010 Eur. Ceram. Soc. 302253 